Canadian

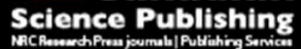

Canadian Journal of Forest Research Revue canadienne de recherche forestière

\title{
Spatial and temporal quantification of forest residue volumes and delivered costs
}

\begin{tabular}{|r|l|}
\hline Journal: & Canadian Journal of Forest Research \\
\hline Manuscript ID & cjfr-2015-0451.R1 \\
\hline Manuscript Type: & Article \\
\hline Complete List of Authors: & $\begin{array}{l}\text { Wells, Lucas; Oregon State University, Forest Engineering, Resources and } \\
\text { Management } \\
\text { Chung, Woodam; Oregon State University, Forest Engineering, Resources } \\
\text { and Management } \\
\text { Anderson, Nathaniel; USDA Forest Service, Rocky Mountain Research } \\
\text { Station } \\
\text { Hogland, John; USDA Forest Service, Rocky Mountain Research Station }\end{array}$ \\
\hline Keyword: & $\begin{array}{l}\text { forest biomass, stand characteristics, treatment residue, bioenergy, stand } \\
\text { delineation }\end{array}$ \\
\hline
\end{tabular}


7 Lucas A. Wells ${ }^{\mathrm{a}, 1}$, Woodam Chung ${ }^{\mathrm{b}, *}$, Nathaniel M. Anderson ${ }^{\mathrm{c}}$, John S. Hogland ${ }^{\mathrm{d}}$

${ }^{a}$ Department of Forest Management, 32 Campus Way, University of Montana, Missoula, MT 59801, 11 USA, Email: lucas.wells@oregonstate.edu

${ }^{\mathrm{b}}$ Department of Forest Engineering, Resources and Management, 276 Peavy Hall, Oregon State

14 University, Corvallis, OR 97331, USA, Email: woodam.chung@oregonstate.edu

${ }^{c}$ Rocky Mountain Research Station, USDA Forest Service, 200 East Broadway, Missoula, MT 59807, USA, Email: nathanielmanderson@,fs.fed.us

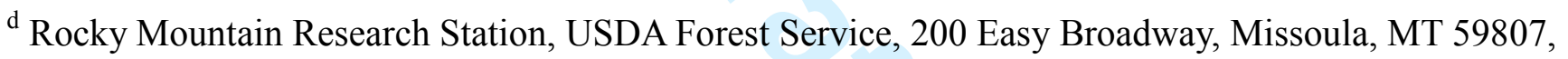
20

* Corresponding author: Tel: 541-737-8248

\footnotetext{
${ }^{1}$ Present address: Department of Forest Engineering, Resources and Management, 068 Peavy Hall, Oregon State University, Corvallis, OR 97331, USA
} 


\section{Spatial and temporal quantification of forest residue volumes and}

\section{1 delivered costs}

\section{Abstract}

34 Growing demand for bioenergy, biofuels and bioproducts has increased interests in the utilization of biomass residues from forest treatments as feedstock. In areas with limited history of industrial biomass utilization, uncertainties in the quantity, distribution, and cost of biomass production and logistics can hinder the development of new bio-based industries. This paper introduces a new methodology to quantify and spatially describe delivered feedstock volumes and costs across landscapes of arbitrary size in ways that characterize operational and annual management decisionmaking. Using National Agricultural Imagery Program (NAIP) imagery, the forest is segmented into operational-level treatment units. A remote sensing model based on NAIP imagery and Forest Inventory and Analysis plot data is used to attribute treatment units with stand-level estimates of basal area, tree density, above ground biomass, and quadratic mean diameter. These methods are applied to a study site in southwestern Colorado to assess the quantity and distribution of treatment residue for use in bioenergy production. Results from the case study demonstrate how this generalized approach can be used in the analysis and decision-making process when establishing new bioenergy industries that use forest residue as feedstock. 


\section{Introduction}

54 The interior west of the United States has experienced growing interests in using forest biomass as a renewable source of energy. Historically the use of forest biomass has been dominated by the forest products industry for generating heat, steam, and electricity (Guo et al., 2007). However, emerging markets for forest biomass as a fuel and feedstock for bioenergy applications can be found throughout the U.S. In the western U.S., interests in these potential and emerging markets are closely linked to the increasing risk of significant forest disturbances, such as fire, insects and disease, and by the broad agreement that silviculture using active treatments, including thinning and prescribed fire, is urgently needed to restore historic stand dynamics and improve forest health (Brown et al., 2004). The large potential treatment area throughout the western U.S. presents opportunities to increase the use of renewable energy sources and stimulate local economic development with new bioenergy and biobased products enterprises that will use the woody biomass byproducts produced by these treatments. In the 15 Western States there are at least 11 million hectares (ha) that could benefit from some type of treatment to restore ecosystems, protect water and soil quality, and improve forest and rangeland resilience (Rummer et al., 2003). Assuming such management occurs only on forests with annual timber production of at least $21 \mathrm{~m}^{3} \mathrm{ha}^{-1}$ per year, an estimated biomass availability of 245 million dry tonnes $(\mathrm{t})$ could result from forest treatments on 4.3 million ha in the west (Western Governors' Association, 2005). The U.S. Department of Energy and USDA Forest Service estimated that an annual supply of 907 million t of biomass would displace $30 \%$ or more of domestic petroleum consumption. Of this amount, the continental U.S. could potentially produce 429 million $\mathrm{t}$ at $\$ 54.43 \mathrm{t}^{-1}$ from forest residue and agricultural waste in 2012 (US DOE, 2011).

Recent studies have evaluated the benefits associated with the use of treatment residues for bioenergy production. Gan and Smith (2007) found that removing logging residues would save \$495620 per ha in site preparation costs during forest regeneration in East Texas. Results from Jones et al. 
77 (2010) show that bioenergy, as an alternative to on-site burning, generates fewer carbon dioxide, 78 methane, and particulate matter emissions. Loeffler and Anderson (2014) examined emissions from 79 co-firing forest biomass with coal and found at $20 \%$ substitution, or $120,717 \mathrm{t}$ of forest biomass per 80 year, total system emissions decreased $15 \%$ for $\mathrm{CO}_{2}, 95 \%$ for $\mathrm{CH}_{4}, 18 \%$ for $\mathrm{NO}_{\mathrm{x}}, 82 \%$ for $\mathrm{PM}_{10}$, and $8127 \%$ for $\mathrm{SO}_{\mathrm{x}}$. Furthermore, there could be economic benefits in using revenues from biomass to offset restorative treatment costs (Brown et al., 2004).

The availability of biomass at tactical and operational scales relies on many factors such as current biomass stocks, harvesting systems, terrain, road network, species, forest characteristics, silviculture, ownership, public policy and regulation, local markets and management objectives, yet these factors are often ignored in large-scale forest biomass supply models that focus on biomass stocks. This is largely attributable to the complexity of forest landscapes and the difficultly in modeling spatial and temporal details of forest management activities. There is a need for an integrated framework to provide realistic forest biomass supply and costs of feedstock across a large landscape at a tactical resolution that takes into account forest inventory, existing infrastructure, and current forest management objectives applied across multiple scales and time frames. A standardized approach for carrying out such an assessment does not exist and likely is not possible given the variability in forests, management practices, and policies across the western U.S. Nonetheless a workflow to guide these types of assessments and tools to help decision makers quantify and spatially describe treatment residue supply volumes are needed to accompany a growing bioenergy enterprise. Broadly, providing high-resolution estimates of biomass stocks and potential flows from restoration treatments at spatial and temporal scales that are relevant to industry is critical for facility capitalization, construction and planning. Operationally, in the context of meeting non-market forest restoration objectives, managers can identify and prioritize treatments with costs that are well matched with both overall demand and the market price of biomass. The overall effect of offsetting the costs of restoration treatments with 
101 revenues from both timber and biomass would be to allow forest managers to treat more acres at lower 102 cost.

103 The objectives of this study are to 1) develop a generalized workflow to evaluate forest biomass

104 utilization and bioenergy supply at tactical and operational scales through space and time and 2)

105 demonstrate the utility of the proposed methodology via application to a study area in southwestern

106 Colorado.

107

1082 Methods

109 The central components of the presented methodology and their role in the workflow are highlighted in

110 Figure 1. The workflow consists of three process modules: stand characterization, treatment

111 simulation, and feedstock cost estimation. In the first module we use modern remote sensing and image

112 processing techniques to produce forest stand boundaries and stand descriptive statistics. These

113 outputs are then coupled with site specific silvicultural prescriptions in the second module to estimate

114 retention, merchantable yield and resulting recoverable biomass residue volumes. The third module

115 routes the recoverable biomass volumes to a conversion facility by least-cost route, and estimates

116 delivered costs of feedstock. Since it is difficult to describe some of the methods in the absence of a

117 site specific example, we present the generalized, non-site specific methods (i.e., stand characterization

118 module) in the following section, then present the subsequent modules in Sections 2.2 and 2.3 after

119 introducing the case study area and site specific data.

\section{$121 \quad 2.1$ Stand characterization module}

122 2.1.1 Imagery

123 Imagery of the National Agricultural Imagery Program (NAIP) was used to estimate forest

124 characteristics and define potential treatment units. NAIP acquires aerial digital orthophotos during the 
125 agricultural growing seasons and the imagery is publicly available within a year of acquisition. The

126 imagery has a $1 \mathrm{~m}$ ground sample distance (1 $\mathrm{m}$ spatial resolution) with a horizontal accuracy of within

$1276 \mathrm{~m}$ at a 95\% confidence level (USDA-FSA-APFO, 2011) and a temporal resolution of 2 to 5 years.

128 The default spectral resolution is natural color (RGB) with an option to include the near infrared band.

129 The configuration used in this study was a 3 band composite including near infrared, green and blue

130 bands (Color-infrared).

\subsubsection{Stand delineation}

133 An automated forest segmentation algorithm (Wells, 2013), hereinafter referred to as the stand

134 delineation algorithm (SDA), was developed in this study to delineate forest landscapes into

135 operational-level treatment units. The SDA employs a series of image filtering techniques and the

136 mean-shift algorithm (Fukunaga and Hostetler, 1975) to decompose NAIP imagery into individual

137 forest stands defined as "a contiguous group of trees sufficiently uniform in age-class distribution,

138 composition and structure, and grown on a site of sufficiently uniform quality to be a distinguishable

139 unit" (Helms, 1998). These processes are embedded in a subspace, multi-scale framework to

140 circumvent computational limitations associated with large scenes of very high resolution imagery.

141 The algorithm uses 12 digit hydrological unit (USGS, 2006) boundaries, also called sub-watersheds, as

142 initial subspace geometries. New geometries created by the segmentation process within each sub-

143 watershed are stored in a vector database and used to further subset the image in the next iteration. As

144 objects become smaller, finer resolutions are used for segmentation to locate features that may not be

145 visible at coarser scales. The algorithm can also be parameterized to comply with minimum and

146 maximum treatment unit area constraints. Minimum and maximum treatment unit area constraints

147 were 2 and 40 ha respectively.

148 The algorithm begins by querying geometry $i$ from database $j$ (figure 2). If geometry $i$ is less than 
149 the maximum specified treatment unit size and greater than the minimum specified treatment unit size

150 then the geometry is not segmented further. It is appended to vector database $j+1$ and the algorithm

151 moves to the next geometry $i+1$. If the geometry is less than the minimum specified treatment unit

152 size, then adjacent geometries are located and geometry $i$ is merged with the candidate adjacent

153 geometry most alike in terms of the average spectral value. If geometry $i$ is greater than the maximum

154 specified treatment unit size then the imagery within the geometry is extracted for segmentation.

155 The next step tests if the extracted image results in memory saturation. If the image is too large, it

156 is resampled by iteratively decreasing the resolution (i.e. $1 \mathrm{~m}, 2 \mathrm{~m}, 4 \mathrm{~m}, 8 \mathrm{~m}, 16 \mathrm{~m}$, etc.) until the

157 image can be stored in memory. Once the image is sufficiently resampled it is convolved with a $3 \times 3$

158 Gaussian filter $(\sigma=0.5)$ and 50 iterations of the anisotropic diffusion filter (time step $=0.125)$. Next

159 the mean shift algorithm segments the image grouping cells to their associated local maxima and

160 labelling groups sequentially. The resulting labeled raster is vectorized and appended to database $j+1$.

161 In some cases the new geometry $i$ in database $j+n$ could match geometry $i$ in database $j+(n-1)$

162 if the chosen resolution for segmentation is the same resolution at which geometry $i$ in database $j+(n-$

163 1) was processed. If this occurs the spectral radius parameter of the mean shift algorithm is iteratively

164 reduced by one until new geometries are created. Reducing this parameter allows the mean shift

165 segmentation to produce more geometries with similar spectral values as opposed to merging these

166 modes as one cluster. When new geometries are created, they are appended to vector database $j+1$.

167 Once all geometries in database $j$ have been processed the algorithm iterates through the

168 geometries in database $j+1$. When all the geometries in database $j+n$ meet the minimum and

169 maximum unit size criteria the final vector database is rasterized to a 1 meter resolution and the dataset

170 is smoothed. Next the smoothed raster is vectorized and the process is terminated. The hierarchy of

171 spatial vector data is used in figure 2 where "layer" describes the database where geometries or

172 "features" are stored. 
173 The resulting stand boundaries were assessed qualitatively by visual evaluation and quantitatively

174 by minimum, maximum and average area and shape compactness value. Compactness is a

175 proportional metric between the area of a feature and the area of a circle having the same perimeter of

176 said feature. Compactness was determined an important measure from a forest operations perspective

177 due to inefficiencies in elongated (non-compact) areas where the area to perimeter ratio is low. The

178 compactness value was calculated by $A_{i} / \pi\left(\frac{P_{i} / \pi}{2}\right)^{2}$ where $A_{i}$ is equal to the area of the stand and $P_{i}$ is

179 the perimeter of the stand. Thus, a stand with a compactness value of 1 would be a circle.

180

181

182

\subsubsection{Stand characteristics}

183 Stand characteristics including basal area, tree density, and above ground biomass are estimated for

184 each treatment unit using the Forest Characteristics Model (FCM) (Hogland et al., 2014). The FCM is

185 a two-tiered remote sensing model where the first stage performs a probabilistic classification of

186 identifiable patterns (e.g. tree canopy, shadow, grass, or water) within NAIP imagery. The

187 classification is the result of a polytomous logistic regression scheme (Hogland et al., 2013) employing

188 a collection of texture derivatives as explanatory variables. The classification output and texture

189 derivatives of each class are summarized for the spatial footprint bounding the four subplots of a FIA

190 field plot and related to average plot estimates of basal area, tree density, and above ground biomass

191 using multivariate linear regression. The result is a multiband raster dataset where each pixel $\left(1 \mathrm{~m}^{2}\right)$

192 represents mean plot estimates of forest characteristics for each species group. Above ground biomass

193 estimates are derived from equations found in Jenkins et al. (2003) and thus can be used to calculate

194 stump, bole, top, and foliage biomass components. Quadratic mean diameter $(\mathrm{cm})$ is added to the

195 dataset post hoc by $\left(B A /\left[k \times t_{d}\right]\right)^{1 / 2}$ where $B A$ is basal area $\left(\mathrm{m}^{2} \mathrm{ha}^{-1}\right), t_{d}$ is tree density $\left(\mathrm{stems} \mathrm{ha}^{-1}\right)$, and

$196 k=0.00007854$ (foresters constant). For model validation methods and results see Wells (2013). 


\subsection{Treatment simulation module}

199

200 The treatment simulation and feedstock cost estimation modules in this study require site specific data. 201 To facilitate effective presentation of the two modules, we introduce our case study area and follow 202 with a description of the modules.

\subsubsection{Case study area}

205 The study area includes the extent of the Uncompahgre Plateau National Forest (UPNF). The UPNF covers approximately 235,000 ha on the west slope of the Colorado Rocky Mountains. Stretching northwest to southeast for 200 kilometers $(\mathrm{km})$, the plateau ranges in elevation from 1,700-1,800 $\mathrm{m}$ in canyon bottoms to upland elevations around 2,500-3,000 m. Three primary vegetation strata occupy the plateau. Pinyon-juniper (Pinus edulis, Juniperus osteosperma, Juniperus scopulorum) cover occurs at the lower elevations ranging from 1,800 to 2,100 m, Gamble oak and Ponderosa pine (Quercus gambelii, Pinus ponderosa) forests inhabit elevations from 2,200 to 2,700 $\mathrm{m}$ and occur in both mixed and pure stands. The upland zone is dominated by aspen (Populus tremuloides), mixed-conifer and spruce-fir (Picea engelmannii, Abies lasiocarpa) forests.

Schmidt et al., 2002), suggesting that these areas exhibit fuel conditions that are conducive to uncharacteristic, high intensity fires. The potential for these disturbance events have initiated active restoration management across the plateau to reduce fuel loading in mixed-conifer and Ponderosa pine, increase diversity in age, size and seral conditions in spruce-fir, regenerate damaged aspen stands from sudden aspen decline, and mitigate pinyon-juniper encroachment into native grasslands and sagebrush ecosystems. 
221 The renewable energy portfolio standard recently implemented in Colorado has stimulated the 222 need to incorporate a higher level of renewable resources into energy production systems, including 223 wind, solar, and biomass. Co-firing biomass with coal has been explored as an option to meet this 224 standard (Loeffler and Anderson, 2014). Though not currently a source of biomass demand, in this 225 study a 100 megawatt coal fired electric power plant located approximately $16 \mathrm{~km}$ west of the eastern 226 border of the study area served as the hypothetical bioenergy facility. Although this particular power 227 plant is fueled completely by bituminous coal, it could be retrofitted to co-fire forest biomass.

\subsubsection{Modeling silvicultural prescriptions and prioritizing stands for treatments}

230 GIS coverage of forest roads on the UPNF was used to query accessible treatment units. These units 231 were defined as having a centroid that fell within maximum skidding distance for whole tree harvesting 232 from an existing road edge, assumed to be $610 \mathrm{~m}$ (2,000 feet) in this study. Three quantifiable 233 silvicultural prescriptions were developed to model removal and retention of biomass on candidate 234 treatment units. These prescriptions are generalized and adapted from the current forest plan for the 235 Uncompahgre National Forest (UPNF Current Forest Plan, 2012) and from a management plan 236 assembled by the Uncompahgre Plateau Collaborative Restoration Project (UPCRP). Management 237 planning documents provided detailed information regarding current conditions, including problems 238 with forest health, reference conditions, and desired future conditions. Stands assigned to a 239 silvicultural prescription are a subset of the accessible treatment units and classified as candidate 240 treatment units. Such stands are included in the selection pool as potential treatment units, but may or 241 may not receive treatment under a given scenario.

242 Stands were categorized into species groups based on a basal area weighted species composition.

243 Pure stands were considered to have a composition of at least $80 \%$ in a single species. Species groups 244 describing two species were stands with an additive composition of $80 \%$ in two species. Mixed-conifer 
245 species group distinguishes stands with a composition of at least $80 \%$ of any combination of spruce-fir, 246 pine, and aspen. Current treatment prescriptions and associated logging systems (e.g. mechanized 247 thinning with whole tree skidding) in spruce-fir, mixed-conifer, aspen and pine stands present 248 opportunities for residue extraction due to the centralization of residues during whole tree harvesting 249 (above the stump) operations. In contrast, treatments in other species groups - such as pinyon-juniper 250 and gamble oak - where mastication, lop-and-scatter and decentralized pile burning are deployed have 251 logistics limitations that reduce potential for biomass residue extraction. Specifically, harvest and 252 collection of biomass residues left behind after these types of treatments can be extremely expensive 253 because the materials are spread over large areas rather than centralized. Therefore only species groups 254 commonly treated with whole-tree skidding are included in this study. These species groups are used 255 to apply a silvicultural prescription to candidate treatment units for the purpose of estimating how 256 much residue will be produced from the activity. These prescriptions include stocking-based, 257 regeneration, and restoration.

258 Stocking-based management - This study uses stocking-based management prescriptions, which 259 reduce stand density for fuels reduction. This approach is commonly applied to spruce-fir and mixed260 conifer forest types in the study area. Stand density index, introduced by Reineke (1933), was used to 261 develop silvicultural guidelines specific to the selected stands. The maximum stand density index 262 (SDI) was located by plotting tree density against quadratic mean diameter $\left(D_{q}\right)$ for all stands selected 263 for stocking-based management on log-log axes. A line with a slope of -1.605 , suggested by Reineke 264 (1933) as the cross-species slope of the 100\% stocking line, was hand fitted on the right edge of the 265 data. Trees ha ${ }^{-1}$ was then indexed where the $100 \%$ stocking line and $D_{q}=25 \mathrm{~cm}$ intersected, resulting 266 in a maximum SDI of 717 trees $\mathrm{ha}^{-1}$. For the purpose of the this analysis the hand fitting method was 267 considered sufficient at removing enough subjectivity in locating maximum SDI since the slope of the 268 line was constrained to -1.605. See Zhang et al. (2005) for a comparison of more objective methods for 
269 fitting the self-thinning line.

270 Relative density (RD) was calculated for each stand by dividing SDI by the maximum SDI (717).

271 Stands with a $\mathrm{RD} \geq 60 \%$ were considered candidate stands for a treatment during the simulation time

272 frame. The target management zone was bounded by a lower zone at 35\% of maximum SDI and an

273 upper zone at $60 \%$ of maximum SDI. When a given stand was selected for treatment, it was assumed

274 that the treatment would reduce the stand's SDI to $47.5 \%$ (half of the distance between the lower and

275 upper management zones) of the maximum SDI. Stands were prioritized by iteratively selecting the

276 highest RD then removing the stand from the selection pool. This approach facilitates efficient

277 treatment application by prioritizing the densest stands for treatment.

278 Regeneration management - Regeneration management was applied to pure aspen stands and aspen

279 stands with a conifer component no greater than $40 \%$. Two important aspects of aspen management

280 across the study area are sudden aspen decline (SAD) and conifer encroachment. The management

281 goal in both situations is to establish a vigorous regenerative age class of aspen. Branch dieback in

282 aspen stands was first noted in southwestern Colorado in 2004 (Worrall et al., 2008) and soon after

283 dubbed "sudden aspen decline", characterizing the sudden, rapid progression of the disease. To this

284 end, the etiology of SAD has been widely studied and recent assessments suggest that SAD appears to

285 have a strong correlation with climate and SAD-like events commonly occur earlier in regions with

286 higher temperatures and drier climates (Hogg, 1997; Shields Jr. and Bockheim, 1981).

287 Results from Worrall et al. (2010) conclude that the areas experiencing the greatest mean

288 moisture deficit during the drought of 2002 showed the highest degree of decline in 2008. This was

289 statistically tested by relating climate moisture index (CMI) values to inventoried aspen stands. Since

290 outputs from the FCM do not provide information regarding mortality, aspen management was

291 prioritized by calculating CMI for the study area and allocating treatments to stands with the highest

292 susceptibility to decline in the event of extreme heat and moisture deficiency. 
CMI is an index of moisture surplus or deficit, simply precipitation minus potential

evapotranspiration. CMI was calculated using an approach outlined by Hogg (1997). Monthly PRISM

climate data (Daly et al., 2009) for 2002 (year of drought) on a 4-km grid and a digital elevation model

with $10 \mathrm{~m}$ spatial resolution were obtained covering the extent of the study area. The 2002 annual CMI

was determined by summing the monthly CMI values. These values were used to locate susceptible areas during extreme conditions similar to the drought of that year.

Since multiple stands fell within each CMI grid cell, auxiliary information was needed to further prioritize treatments. To augment CMI, the topographic wetness index (TWI) was calculated for the study area using the elevation dataset. Topography affects the spatial distribution of soil moisture and sub-surface flow often follows surface topography (Rodhe and Seibert, 1999; Seibert et al., 1997; Zinko et al., 2005). Therefore this index has been used to depict spatial soil moisture patterns (Burt and Butcher, 1986; Moore et al., 1991). TWI provided local information regarding potential stress in aspen stands due to moisture deficit within each 4-km cell of the CMI. TWI was computed by $\ln (a /$ $\tan \beta$ ) where $a$ is the local upslope area draining through a certain point per unit contour length and $\tan \beta$ is the local slope (Beven and Kirkby, 1979). stands with the lowest average TWI value. When a given stand encountered a treatment event, a regeneration cut was simulated removing $100 \%$ of the estimated growing stock and subtracting merchantable yield to estimate the amount of treatment residue.

Restoration in ponderosa pine - Restoration treatments were applied to pure ponderosa pine stands as well as aspen-pine and juniper-pine stands with a pine component of at least $60 \%$. The majority of 314 ponderosa pine stands across the plateau no longer exhibit the structure that was common in the $19^{\text {th }}$ 315 century (Binkley et al., 2008). Historically these stands had a clumped distribution, interspersed with 316 small (0.04 to 0.2 ha) meadows and basal area ranging from 5 to $20 \mathrm{~m}^{2} \mathrm{ha}^{-1}$. Many of the stands on the 
317 plateau exceed $20 \mathrm{~m}^{2} \mathrm{ha}^{-1}$ and few well over $35 \mathrm{~m}^{2} \mathrm{ha}^{-1}$. Restoration treatments for ponderosa pine in

318 this study reduced basal area to $5-11 \mathrm{~m}^{2} \mathrm{ha}^{-1}$ following recommendations from Binkley et al. (2008).

319 The basal area of each treated stand was reduced to $8 \mathrm{~m}^{2} \mathrm{ha}^{-1}$. Treatments were prioritized by

320 iteratively selecting the stand with the highest basal area value and thinning to the target basal area.

321 Treatment residues were calculated by subtracting retention and merchantable yield from above ground 322 biomass for each treated stand.

\subsubsection{Treatment residue volumes}

325 Residue was estimated for each candidate treatment unit by first subtracting the removed biomass from 326 the total above ground biomass then subtracting gross merchantable yield. The amount of removed 327 biomass was determined by the silvicultural prescription while the gross merchantable yield was 328 calculated by using a component ratio estimator for stem wood and stem bark based on qmd and tree 329 length from a $30 \mathrm{~cm}$ stump height to a $10 \mathrm{~cm}$ top diameter (Jenkins et al., 2003). Total treatment 330 residues were reduced by $30 \%$ to account for the leakage during transport from stump to landing and 331 the recovery rate of the residue at the landing (Baral and Guha, 2004; Fight et al., 2006). These 332 operational constraints also effectively leave a significant amount of woody biomass on the unit to 333 meet guidelines for retention associated with soil and biodiversity objectives (Abbas et al., 2011). 334 Equation 1 was used to calculate treatment residue (TR) where $B_{a g}$ is above ground biomass, $B_{s r}$ is 335 silviculturally retained biomass (biomass units in dry tonnes per hectare). $\beta_{0}$ and $\beta_{1}$ are the species336 specific component ratio coefficients for stem wood and stem bark, $D_{q}$ is the quadratic mean diameter 337 for the stand and $r$ is the reduction factor of leakage and recovery rates $(0.7)$. Residue extraction was 338 assumed to take place after the removal of the commercial component and residue was allowed time to 339 dry to a moisture content of $30 \%$ (Han et al., 2010). 


$$
T R=r\left(\left[B_{a g}-B_{s r}\right]\left[1-e^{\beta_{0}+\frac{\beta_{1}}{D_{q}}}\right]\right)
$$

\subsection{Feedstock cost estimation module}

The harvesting system for each treatment was assumed to be mechanical felling with a feller-buncher followed by whole-tree skidding where the tops and limbs of the removed trees were transported with the bole to a road side landing designated for each unit. The extraction operation was assumed to be road-side processing and biomass grinding since all candidate treatment stands were selected to be within the maximum skidding distance of $610 \mathrm{~m}$ to unit centroid from the existing road network. A marginal cost approach was used to calculate forest operations costs (Puttock, 1995). This approach considers biomass to be a byproduct of the production of higher value components like sawlogs, and fully allocates harvest costs of felling, extraction, processing, road construction, and stumpage to these products. Therefore costs begin to accrue with the collection of residues at the roadside. Handling, processing and loading costs for residues were calculated following methods from Anderson (2011) by averaging the results from 40 scientific studies examining biomass removal from timber harvest, fuel treatments, and other residue related operations resulting in $\$ 31.14 \mathrm{t}^{-1}$. round trip delivery times, denoted by variable $h$ (hours [hr]) in Equation 2, from each unit to the potential bioenergy facility were calculated using a GIS coverage of all UPNF roads. A transportation network optimization program was used to determine the least cost route for each unit based on engineered road speed (Chung and Sessions, 2003). Other variables used to calculate transportation 362 costs were load time $(l)$ and unload time $(u)$ each assumed to be $0.5 \mathrm{hr}$, non-fuel trucking (operator) 363 cost (c) set at $\$ 48.03 \mathrm{hr}^{-1}$ (ATRI, 2013), a specialized trucking premium ( $p$ ) of $\$ 12.00 \mathrm{hr}^{-1}, \$ 1.04 \mathrm{~L}^{-1}$ for 364 diesel fuel price (d) (US EIA, 2013), average fuel economy ( $s$ ) of $1.98 \mathrm{~km} \mathrm{~L}^{-1}$, average truck speed ( $v$ 
$\left.365\left[\mathrm{~km} \mathrm{hr}^{-1}\right]\right)$ which depends on the engineered road speed of the shortest path distance for each unit, 366 lubrication price $(a)$ set at $10 \%$ of the diesel fuel price assumed to correlate perfectly with diesel fuel 367 price, van capacity $(m)$ of $27.22 \mathrm{t}$, and biomass moisture content $(w)$ of 0.3 (Anderson, 2011). 368

$$
T=\frac{(h+l+u)\left\{c+p+\left(d\left[1+\frac{a}{100}\right] s^{-1} v\right)\right\}}{m(1-w)}
$$

\subsection{Management scenarios for the case study area}

372 A 10 year management simulation was conducted to estimate delivered feedstock volume and costs under current site-specific management objectives. The annual treatment area constraint was set according to management planning documents developed by the US Forest Service and UPCRP.

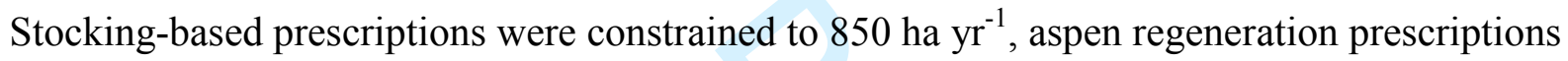

year that a given stand gets treated depends on the order in which the stands are selected for treatment (defined in the silvicultural prescription) and the annual treatment area constraint for that prescription.

Once a unit is selected for treatment it is no longer considered a candidate treatment unit for the duration of the simulation. The annual delivered volumes and costs are calculated for each species group (silvicultural prescription).

A second scenario was carried out to evaluate how treatment area (total area treated during the next 10 years) affects the quantity of treatment residue volume and the spatial distribution of treatments. The purpose of this analysis is to identify the capacity of the landscape in terms of feedstock supply and characterize how delivered costs change as allowable treatment area increases. total candidate area, the treated area was increased iteratively by $10 \%$ until $100 \%$ of the candidate treatment area was selected for treatment. The area allocations to the prescriptions described in the 
current management scenario were proportionally consistent for each $10 \%$ augmentation. Total available residues were calculated for each $10 \%$ increase in allowable treatment area. candidate treatment unit and categorized into $\$ 5$ increments. The available residues were summed for each delivered cost category. From a market perspective, the assumption in this analysis is that residues generated from treatment would be supplied to end-users at a market price at or above the specified delivered cost, but that residues with higher costs would probably be burned in place for disposal because utilization would represent higher net costs than disposal.

\section{Results and discussion}

\subsection{Stand delineation and characteristics}

402 Stand boundaries were assessed by visual evaluation, compliance with the size restrictions, and the 403 overall shape compactness value. The visual assessment consisted of scanning all stand boundaries superimposed on the NAIP imagery and checking for delineations that were incongruent with vegetation patterns observed in the imagery. Manual alterations of the stand boundaries were not necessary. Some of the boundaries separated apparently homogeneous and contiguous areas of forest cover. This is a result of the maximum stand area restriction and the algorithms' ability to numerically discriminate areas that might not be easily distinguishable by the human eye. This visual assessment was carried out only to identify any unexpected errors in the algorithm and to help fine tune algorithm parameters during the testing phase. The authors feel that visual assessment of all stand boundaries

411 will not be necessary if the SDA is implemented on similar landscapes. However, if the SDA is used in 412 a forest that is dissimilar in composition and structure than that of the present study site, then visual 
413 assessment is recommended.

414 The average size of the delineated stands was 9.2 ha $(S D=10.3)$. All stands met the minimum 415 and maximum size restrictions with a minimum size of 2.95 ha and a maximum of 39.97 ha. The 416 average shape compactness value was $0.49(S D=0.14)$ with a maximum value of 0.89 and a minimum 417 of 0.11 . In many cases compactness values less than 0.2 were a result of the segmentation algorithm 418 following roads and streams yielding elongated shapes with poor compactness values. Buffering roads 419 and streams prior to carrying out segmentation would likely resolve this issue and increase the average 420 compactness value.

421 Figure 3 shows the distribution of cover types across the UPNF. Cover types including scrub422 oak, mountain mahogany, and other species cover $25.5 \%$ of the plateau. Mixed-conifer had the second 423 highest coverage of $22.4 \%$. Pinyon-Juniper occupies $12.8 \%$ of the plateau, covering mostly the lower 424 elevations on the east and west extents. Pure aspen stands occur on the higher elevations covering 425 approximately $8.5 \%$ of the plateau. Ponderosa pine, spruce-fir, and other mixed-species (pine-juniper, 426 aspen-pine) stands cover the remaining of the forested area and non-forested areas account for 427 approximately $8 \%$ of the landscape. The values in table 1 represent stand statistics for forest types 428 across the study area. Forest types not assigned to a silvicultural prescription in treatment simulations 429 are included to demonstrate the utility of the SDA and the FCM, which were conducted for the entire 430 study area.

\subsection{Silvicultural prescriptions}

433 The selection of accessible forest stands resulted in 13,887 stands of the total 25,538 or $54 \%$ of the 434 total area. A total of 5,297 stands within the accessible area were considered candidate treatment units. 435 The remaining accessible stands were given a "no treatment" prescription because they 1) currently 436 meet desired future conditions, 2) are in early seral stage, or 3) are composed of a species group that is 
437 either not targeted or has high biomass logistics costs. Figure 4 shows the location of candidate 438 treatment units by silvicultural prescription. These stands totaled to 46,840 ha with 20,228 ha, 8,102 ha 439 and 18,510 ha in stocking-based, regeneration and restoration respectively.

\subsection{Feedstock volume and delivered costs}

442 Operations costs were calculated for all accessible stands across the study area. These costs represent 443 handling, processing and loading cost plus round trip transportation cost to the bioenergy facility. 444 Operations costs were close to normally distributed and ranged from $\$ 34.77 \mathrm{t}^{-1}$ to $\$ 51.13 \mathrm{t}^{-1}$ with a 445 mean of $\$ 42.57 \mathrm{t}^{-1}(S D=3.28)$. These costs correlate perfectly with travel distance to the bioenergy 446 facility since in-woods operations costs were fixed.

\subsubsection{Current management}

449 The 10 year management simulation resulted in 18,564 treated ha and 463,726 t of available treatment 450 residue. The area treated is less than the constraint (18,820 ha) as when a stand is selected for 451 treatment the entire stand must be treated, not a portion of the stand. Figure 5 illustrates the 452 distribution of selected treatment stands for each simulated year. The distribution of delivered costs for 453 each year is shown in figure 6. Year 6 had the largest range of delivered costs of $\$ 34.18$ to $\$ 50.91 \mathrm{t}^{-1}$.

454 The lowest average delivered costs was $\$ 42.02 \mathrm{t}^{-1}$ during year 2 and the highest during year 10 at $455 \$ 42.98 \mathrm{t}^{-1}$. The average delivered cost for the 10 year simulation was $\$ 42.54 \mathrm{t}^{-1}(S D=3.24)$.

Although the area constraints were held constant throughout the simulation, the available residue 457 decreased each year (table 2). This was a result of treatment prioritization targeting higher stocked 458 stands in the beginning of the simulation. It is worth noting that this decreasing trend is likely to 459 persist if the simulation is continued for a longer planning horizon. This is in part due to the absence of 460 forest growth in the presented methodology as under stocked stands may grow into overstocked stands 
461 during the 10 year planning horizon, but it is primarily attributable to the treatment prioritization

462 schemes that were based on ecological goals: restorative management regimes targeted at overstocked 463 stands tend to produce large amounts of treatment residue including non-merchantable small-diameter 464 trees. The long-term management goal of restoration means that more hectares of forest will be 465 changed from current overstocked conditions to a state that more closely represents historic reference 466 conditions, especially if periodic low-intensity natural and prescribed fires are used as a management 467 tool to maintain understory conditions where appropriate. It is expected that available residue volumes 468 will continue to decrease as the forests approach the desired future conditions. Note that the stands 469 selected for treatments account for only $8 \%$ of the total area while the above ground biomass in these 470 stands account for $15 \%$ of the total (table 3 ). In theory, available residue will stabilize assuming that 471 management intensity (treatment area constraints) remain constant and restoration efforts involve 472 natural mechanisms, such as fire, to maintain historic stand densities and structure.

473 From a biomass supply perspective, it is important to recognize that restoration treatments differ 474 from even-aged silviculture for timber management, which includes periodic over story removal to 475 harvest mature timber and regenerate the stand, and is capable of supplying a sustained yield of 476 biomass residues associated with timber harvest. We would not expect such a decline in available 477 residues in an even-aged timber management context.

\subsubsection{Augmented allowable treatment area}

480 The augmented treatment area simulation resulted in a linear increase in treatment residue from $481499,735 \mathrm{t}$ to $960,905 \mathrm{t}$ at $50 \%$ and $100 \%$ of candidate treatment area respectively. The $50 \%$ allowable 482 treatment area was considered the base case condition since the area treated was similar to that of the 483 current management scenario. Each 10\% increase in allowable treatment area added approximately $4849,000 \mathrm{t}$ of available treatment residue. Conceivably, the proportion of residue in each silvicultural 
485 designation remains roughly consistent during each $10 \%$ increase in allowable treatment area (figure

486 7). The average annual available treatment residue was $49,974 \mathrm{t}$ per year $(S D=3,854)$ at $50 \%$

487 treatment area and culminated at $100 \%$ yielding 96,091 t per year $(S D=5,415)$ of residue. The spatial

488 distribution of residues in this scenario was similar to that of the current management scenario, thus the

489 delivered cost per $\mathrm{t}$, which hinges on transportation cost, remains relatively consistent during each $10 \%$

490 increase in treatment area. The average delivered cost for all treatment area augmentations was $\$ 41.89$

$491 \mathrm{t}^{-1}(S D=3.43)$. Figure 8 shows the location of stands selected at $50 \%$ (black) and $100 \%$ (gray)

492 allowable treatment area.

493 Stocking-based management was assigned to the mixed-conifer and spruce-fir species groups and 494 accounted for the largest percentage (43\%) of the total candidate treatment area. Therefore the 495 stocking-based prescriptions produce the largest percentage of available residue at all treatment levels. 496 Conversely, stands selected for regeneration management, only $20 \%$ of the candidate treatment area 497 produced the second largest percentage of total available residue. This was due to the removal of all 498 growing stock in these stands. Although restoration treatments in ponderosa pine covered $40 \%$ of the 499 candidate treatment area, these stands produced the lowest residue volumes at all treatment levels due 500 to low pretreatment basal area values relative to mixed-conifer, spruce-fir and aspen stands.

501 It is likely that the establishment of a bioenergy supply chain will provide incentives to increase 502 the allowable treatment area. According to these results it is estimated that each $10 \%$ increase (from $50350 \%$ to $100 \%$ ) in allowable treatment area will yield 9,000 t of feedstock without significantly 504 increasing or decreasing delivered costs. This relationship might not be consistent if this analysis is 505 repeated on a managed forest operating at an annual allowable treatment level that is large in 506 proportion to the candidate treatment area. Furthermore, in certain situations increasing the allowable 507 treatment area can have negative impacts on average delivered costs if more treatments are scheduled 508 further away from the bioenergy facility. 
$510 \quad 3.3 .3$ Economic classification of candidate treatment area

511 Figure 9 reveals the spatial structure of delivered costs for residues across the candidate treatment area.

512 Nearly $55 \%(524,154 \mathrm{t})$ of the residues within the candidate treatment area are available at $\$ 40-45 \mathrm{t}^{-1}$

513 and roughly $33 \%\left(321,812 \mathrm{t}\right.$ ) of residues are available at $\$ 45-50 \mathrm{t}^{-1}$ (table 4$)$. These results can be used

514 to prioritize treatments early in the development of a bioenergy supply chain to initiate markets by

515 allocating efforts to residues available at relatively low costs. As markets develop, managers can begin

516 to incorporate the acreage allocation constraints to meet forest-wide desired future conditions.

517 Potential end users can use this information to evaluate feedstock prices that would result in different

518 levels of feedstock supply and production.

519 In certain forests, the primary management focus is to improve forest health using restoration

520 treatments. Commonly, these treatments produce a large amount of low-grade materials with high

521 logistics costs and low market value. Existing markets are typically dominated by fuel markets for

522 electricity production and co-generation of heat and power by forest industry facilities, sometimes with

523 emerging demand by pellet mills and smaller bioenergy and bioproducts facilities. For the UPNF,

524 where $70 \%$ of the forest is in fire regime condition class 2 or 3 and markets are very limited, a strategic

525 approach to biomass analysis can support emerging biomass markets in several ways.

526 In other situations, such as commercial forests where broad-scale restoration is not a primary

527 concern, different strategies may be more appropriate. Nonetheless, this methodology was designed

528 with adaptability in mind to accommodate a range of management objectives across a diversity of

529 landscapes and resources. The NAIP and FIA datasets used in this study have broad national coverage,

530 facilitating similar analysis throughout the United States, but any similar remote sensing and inventory

531 data can be used.

532 


\section{Conclusion}

534 The integration of the stand delineation algorithm and the forest characteristics model coupled with site 535 specific silvicultural prescriptions and operational planning presents the opportunity to carry out 536 detailed spatial analysis for a diversity of resources on very large landscapes. As demonstrated in this 537 study, the methodology can be employed to assess the feasibility of biomass utilization, assist 538 silvicultural decisions, and facilitate operational planning at tactical, and operational scales. The 539 capacity to not only estimate residue quantities, but also map the spatial distribution of stand-level 540 residues following alternative management regimes is vital in areas with limited history of industrial 541 biomass utilization and uncertainties in biomass markets. This information is useful to stakeholders 542 across the biomass supply chain, including land managers, contractors, and end users.

543 Research is still needed to fill the knowledge gap regarding residue leakage from stump to 544 landing and recovery rates at the landing, as well as site-specific forest operations costs. Small changes 545 in leakage and recovery rates can drastically influence estimated biomass availability. Although this 546 study assumed a $70 \%$ reduction rate to account for stump to landing leakage and recovery at the 547 landing, this can vary significantly depending on species, time since harvest, level of stand mortality, 548 and other variables. An improved model would incorporate forest growth in temporal simulation, 549 allowing more accurate estimates well beyond the 10 -year time frame used in this study. This 550 improvement would broaden the planning horizon to better understand the sustainability of biomass 551 flows, as well as the long-term viability of supplying bioenergy and biofuels facilities with biomass 552 from forest restoration treatments. The assumption that the road network will remain static over the 553 next 10 years may result in significant underestimation of potential supply volume. It is recommended that proposed road additions are included, or proposed road decommissions excluded in the presented workflow to deal with changes in accessibility. Future studies could use this methodology to optimally 556 locate bioenergy facilities in the region in ways to reduce feedstock procurement costs, and determine 
557 the scale at which they could operate sustainably, and in balance with forest management regimes that 558 meet a broad range of social, economic and ecological objectives.

\section{Acknowledgements}

562 This research was supported by the Agriculture and Food Research Initiative, Biomass Research and 563 Development Initiative, Competitive Grant no. 2010-05325 from the USDA National Institute of Food 564 and Agriculture and a USFS Rocky Mountain Research Station Grant no. 10-JV-11221636-282 with 565 significant cost match and in-kind support from the University of Montana and Oregon State 566 University.

\section{References}

569

570

571

572

573

574

575

576

577

578

579

580

581

582

583
Abbas, D., Current, D., Phillips, M., Rossman, R., Hoganson, H., and Brooks, K.N. 2011. Guidelines for harvesting forest biomass for energy: A synthesis of environmental considerations. Biomass and Bioenergy 35, 4538-4546. doi:10.1016/j.biombioe.2011.06.029

Anderson, N.M. 2011. Estimating the delivered costs of biomass from the Uncompahgre Plateau using Monte Carlo simulation. A mid-project Summ. Prep. stakeholders, partners Coop. Rocky Mt. Res. Stn. Compet. Res. Initiat. - Uncompahgre Plateau Proj. 1-18.

ATRI, 2013. American Transportation Research Institute. Am. Truck. Assoc. Fed. URL http://atrionline.org/ [accessed 11 October 2013].

Baral, A., Guha, and G.S. 2004. Trees for carbon sequestration or fossil fuel substitution: The issue of cost vs. carbon benefit. Biomass and Bioenergy 27, 41-55. doi:10.1016/j.biombioe.2003.11.004

Beven, K.J. and Kirkby, M.J. 1979. A physically based, variable contributing area model of basin hydrology. Hydrol. Sci. Bull. 24, 43-69. doi:10.1080/02626667909491834

Binkley, D., Romme, B., and Cheng, T. 2008. Historical Forest Structure on the Uncompahgre Plateau : Informing restoration prescriptions for mountainside stewardship. Prepared by the Colorado Forest Restoration Institute ,. Color. For. Restor. Inst. 1-27. 
584

585

586

587

588

589

590

591

592

593

594

595

596

597

598

599

600

601

602

603

604

605

606

607

608

609

610

611

612

613

614

615

616

Brown, R.T., Agee, J.K., and Franklin, J.F. 2004. Forest Restoration and Fire: Principles in the Context of Place. Conserv. Biol. 18, 903-912. doi:10.1111/j.1523-1739.2004.521_1.x

Buchholz, T., Canham, C.D., and Hamburg, S.P. 2011. Forest Biomass and Bioenergy : Opportunities and Constraints in the Northeastern United States. Cary Inst. Ecosyst. Stud. 1-75.

Burt, T. and Butcher, D. 1986. Stimulation from simulation? a teaching model of hillslope hydrology for use on microcomputers. J. Geogr. High. Educ. 10, 23-39.

Chung, W. and Sessions, J. 2003. Network 2000: a program for optimizing large fixed and variable cost transportation systems, in: Proceedings of the Eighth Symposium on System Analysis in Forest Resources, Snowmass Village, Coloardo, USA. pp. 109-120. doi:10.1007/978-94-0170307-9_12

Daly, C., Gibson, W., Doggett, M., Smith, J., and Taylor, G. 2009. Near-real-time monthly highresolution climate data set for the conterminous united states. Spat. Clim. Anal. Serv. Oregon State Univ. Corvallis, OR, USA.

Fight, R.D., Hartsough, B.R., and Noordijk, P. 2006. Users Guide for FRCS : Fuel Reduction Cost Simulator Software. USDA For. Serv. Pacific Northwest Res. Station. Gen. Tech. Rep. PNWGTR-668 1-30.

Fukunaga, K. and Hostetler, L. 1975. The estimation of the gradient of a density function, with applications in pattern recognition. IEEE Trans. Inf. Theory 21, 32-40. doi:10.1109/TIT.1975.1055330

Gan, J. and Smith, C.T. 2007. Co-benefits of utilizing logging residues for bioenergy production: The case for East Texas, USA. Biomass and Bioenergy 31, 623-630. doi:10.1016/j.biombioe.2007.06.027

Guo, Z., Sun, C., and Grebner, D.L. 2007. Utilization of forest derived biomass for energy production in the U.S.A.: status, challenges, and public policies. Int. For. Rev. 9, 748-758. doi:10.1505/ifor.9.3.748

Han, H.S., Halbrook, J., Pan, F. and Salazar, L. 2010. Economic evaluation of a roll-off trucking system removing forest biomass resulting from shaded fuelbreak treatments. Biomass and Bioenergy 34, 1006-1016. doi:10.1016/j.biombioe.2010.02.009

Hardy, C.C., Schmidt, K.M., Menakis, J.P., and Neil, S.R. 2001. Spatial data for national fire planning and fuel management. Int. J. Wildl. Fire 10, 353-372.

Helms, J.A., 1998. The dictionary of forestry. Soc. Am. For. Bethesda, MD. 210 p.

Hogg, E.H. 1997. Temporal scaling of moisture and the forest-grassland boundary in western Canada. Agric. For. Meteorol. 84, 115-122. doi:10.1016/S0168-1923(96)02380-5 
617

618

619

620

621

622

623

624

625

626

627

628

629

630

631

632

633

634

635

636

637

638

639

640

641

642

643

644

645

646

647

648

649

650

651

Hogland, J., Billor, N., and Anderson, N.M. 2013. Comparison of standard maximum likelihood classification and polytomous logistic regression used in remote sensing. Eur. J. Remote Sens. 46, 623-640. doi:10.5721/EuJRS20134637

Hogland, J.S., Anderson, N.M., Chung, W., and Wells, L. 2014. Estimating forest characteristics using NAIP imagery and ArcObjects, in: Proceedings of the 2014 ESRI Users Conference; July 14-18, 2014, San Diego, CA. Redlands, CA: Environmental Systems Research Institute. Online: http://proceedings.esri.com/library/userconf/proc14/papers/155_181.pdf. pp. 1-22.

Jenkins, J.C., Chojnacky, D.C., Heath, L.S., and Birdsey, R.A. 2003. National-scale biomass estimators for United States tree species. For. Sci. 49, 12-35.

Jones, G., Loeffler, D., Calkin, D., and Chung, W. 2010. Forest treatment residues for thermal energy compared with disposal by onsite burning: Emissions and energy return. Biomass and Bioenergy 34, 737-746. doi:10.1016/j.biombioe.2010.01.016

Loeffler, D. and Anderson, N.M. 2014. Emissions tradeoffs associated with cofiring forest biomass with coal: A case study in Colorado, USA. Appl. Energy 113, 67-77.

doi:10.1016/j.apenergy.2013.07.011

Moore, I.D., Grayson, R.B., and Ladson, A.R. 1991. Digital Terrain Modeling : A Review of Hydrological Geomorphological and Biological Applications. Hydrol. Process. 5, 3-30. doi:DOI: 10.1002/hyp.3360050103

Puttock, G.D. 1995. Estimating cost for integrated harvesting and related forest management activities. Biomass Bioenergy 8, 73-79. doi:10.1016/0961-9534(95)00001-N

Reineke, L.H. 1933. Perfecting a stand-density index for even-aged forests. J. Agric. Res. 46, 627-638.

Rodhe, A., and Seibert, J. 1999. Wetland occurrence in relation to topography: A test of topographic indices as moisture indicators. Agric. For. Meteorol. 98-99, 325-340. doi:10.1016/S01681923(99)00104-5

Rummer, B., Prestemon, J., May, D., Miles, P., Vissage, J., McRoberts, R., Liknes, G., Shepperd, W.D., Ferguson, D., Elliot, W., Miller, S., Reutebuch, S., Barbour, J., Fried, J., Stokes, B., Bilek, E., and Skog, K. 2003. A Strategic Assessment of Forest Biomass and Fuel Reduction Treatments in Western States. USDA For. Serv. Res. Dev. Online http//www.treesearch.fs.fed.us/pubs/23846 $18 \mathrm{p}$.

Schmidt, K.M., Menakis, J.P., Hardy, C.C., Hann, W.J., and Bunnell, D.L. 2002. Development of coarse-scale spatial data for wildland fire and fuel management. USDA For. Serv. Gen. Tech. Rep. RMRS-GTR-62.

Seibert, J., Bishop, K.H., and Nyberg, L. 1997. A test of TOPMODEL's ability to predict spatially distributed groundwater levels. Hydrol. Process. 11, 1131-1144. doi:10.1002/(SICI)10991085(199707)11:9<1131::AID-HYP549>3.0.CO;2-\# 
652

653

654

655

656

657

658

659

660

661

662

663

664

665

666

667

668

669

670

671

672

673

674

675

676

677

678

679

680

681

682

683

684
Shields Jr., W.J., and Bockheim, J.G. 1981. Deterioration of trembling aspen clones in the Great Lakes region. Can. J. For. Res. doi:10.1139/x81-073

UPNF Current Forest Plan, 2012. Grand Mesa Uncompahgre and Gunnison National Forests. http://www.fs.usda.gov/detail/gmug/landmanagement/planning/?cid=fsbdev7_003229 [accessed 20 September 2013].

US DOE 2011. US billion-ton update: biomass supply for a bioenergy and bioproducts industry. Oak Ridge Natl. Lab. 228 p.

US EIA 2013. US Energy Information Administration. US Dep. Energy. URL http://www.eia.gov/ (accessed 2 October 2013).

USDA-FSA-APFO 2011. National agricultural imagery program. USDA, Farm Serv. Agency, Aer. Photogr. F. Off. Salt Lake City, Utah.

USGS 2006. Watershed boundary data - 12 digit hydrological units. http://www.ncgc.nrcs.usda.gov/products/datasets/watershed/.

Wells, L.A. 2013. Spatial Distribution and Quantification of Forest Treatment Residues for Bioenergy Production. Thesis, Univ. Mont. Coll. For. Conserv. Dep. For. Manag. http//scholarworks.umt.edu/etd/4177 $118 \mathrm{p}$.

Western Governors' Association 2005. Western Regional Biomass Energy Program. www.westgov.org/wga/initiatives/biomass/.

Worrall, J.J., Egeland, L., Eager, T., Mask, R.A., Johnson, E.W., Kemp, P.A., and Shepperd, W.D. 2008. Rapid mortality of Populus tremuloides in southwestern Colorado, USA. For. Ecol. Manage. 255, 686-696. doi:10.1016/j.foreco.2007.09.071

Worrall, J.J., Marchetti, S.B., Egeland, L., Mask, R.A., Eager, T., and Howell, B. 2010. Effects and etiology of sudden aspen decline in southwestern Colorado, USA. For. Ecol. Manage. 260, 638648. doi:10.1016/j.foreco.2010.05.020

Zhang, L., Bi, H., Gove, J.H., Heath, L.S. 2005. A comparison of alternative methods for estimating the self-thinning boundary line. Can. J. For. Res. 35: 1507-1514. doi:10.1139/X05-070

Zinko, U., Seibert, J., Dynesius, M., and Nilsson, C. 2005. Plant species numbers predicted by a topography-based groundwater flow index. Ecosystems 8, 430-441. doi:10.1007/s10021-003$0125-0$ 
685

686 


\section{Tables}

688

689 Table 1: Summary of forest characteristics by forest type. Values for basal area, density, and above 690 ground biomass represent the mean within the forest type (standard deviation in parentheses).

\begin{tabular}{|c|c|c|c|c|c|c|}
\hline forest type & $\begin{array}{c}\text { \# of } \\
\text { stands }\end{array}$ & $\begin{array}{l}\text { area } \\
\text { (ha) }\end{array}$ & $\left.\mathrm{ha}^{-1}\right)^{\left(\mathrm{m}^{2}\right.}$ & $\begin{array}{c}\text { tpa } \\
\left(\text { stems ha }{ }^{-1}\right)\end{array}$ & $\begin{array}{l}\text { qmd } \\
(\mathrm{cm})\end{array}$ & $\begin{array}{c}\text { agb } \\
\left(\mathrm{t} \mathrm{ha}^{-1}\right)\end{array}$ \\
\hline aspen & 2,123 & 19,866 & $22.96(9.83)$ & $\begin{array}{c}444.79 \\
(192.67)\end{array}$ & $\begin{array}{l}25.40 \\
(0.74)\end{array}$ & $\begin{array}{c}48.99 \\
(21.17)\end{array}$ \\
\hline aspen-pine & 3,015 & 26,852 & $16.76(6.45)$ & $\begin{array}{c}276.76 \\
(124.96)\end{array}$ & $\begin{array}{l}27.94 \\
(1.75)\end{array}$ & $\begin{array}{c}35.38 \\
(14.16)\end{array}$ \\
\hline pinyon-jun & 3,266 & 30,121 & $14.69(6.26)$ & $\begin{array}{l}143.32 \\
(68.5)\end{array}$ & $\begin{array}{l}35.56 \\
(3.46)\end{array}$ & $15.42(6.25)$ \\
\hline juniper-pine & 950 & 8,768 & $10.56(3.79)$ & $\begin{array}{l}111.20 \\
(49.15)\end{array}$ & $\begin{array}{l}35.56 \\
(3.81)\end{array}$ & $15.42(5.59)$ \\
\hline mixed conifer & 5,385 & 52,717 & $25.48(10.69)$ & $\begin{array}{c}509.04 \\
(210.12)\end{array}$ & $\begin{array}{l}25.40 \\
(0.89)\end{array}$ & $\begin{array}{c}53.52 \\
(22.63)\end{array}$ \\
\hline pine & 1,033 & 8,340 & $9.41(2.84)$ & $\begin{array}{c}108.73 \\
(45.79)\end{array}$ & $\begin{array}{l}33.02 \\
(3.94)\end{array}$ & $19.05(6.72)$ \\
\hline spruce-fir & 1,060 & 9,069 & $26.86(12.28)$ & $\begin{array}{c}536.22 \\
(234.78)\end{array}$ & $\begin{array}{l}25.40 \\
(1.27)\end{array}$ & $\begin{array}{c}53.52 \\
(25.79)\end{array}$ \\
\hline other & 6,764 & 59,964 & $18.14(8.76)$ & $\begin{array}{c}318.77 \\
(176.81)\end{array}$ & $\begin{array}{l}27.94 \\
(2.39)\end{array}$ & $\begin{array}{c}30.84 \\
(18.87)\end{array}$ \\
\hline non-forested & 1,943 & 19,142 & - & - & - & - \\
\hline
\end{tabular}

691

692

693

694

695

696

697

698

699

700 
701 Table 2: Area treated, pretreatment above ground biomass, removed biomass, merchantable yield,

702 treatment residue, and available feedstock per year.

\begin{tabular}{|c|c|c|c|c|c|c|}
\hline Year & $\begin{array}{l}\text { area } \\
\text { (ha) }\end{array}$ & $\begin{array}{r}\text { agb } \\
(\mathrm{t})\end{array}$ & $\begin{array}{l}\text { removed } \\
(\mathrm{t})\end{array}$ & $\begin{array}{l}\text { merchantable } \\
(\mathrm{t})\end{array}$ & $\begin{array}{l}\text { residue } \\
(\mathrm{t})\end{array}$ & $\begin{array}{l}\text { feedstock } \\
\text { (t) }\end{array}$ \\
\hline 1 & 1,861 & 392,094 & 193,936 & 111,920 & 73,851 & 51,696 \\
\hline 2 & 1,827 & 354,698 & 191,892 & 118,271 & 73,060 & 51,142 \\
\hline 3 & 1,870 & 337,680 & 184,988 & 114,928 & 70,060 & 49,042 \\
\hline 4 & 1,832 & 317,217 & 178,740 & 111,020 & 67,721 & 47,405 \\
\hline 5 & 1,874 & 311,540 & 181,018 & 112,418 & 68,600 & 48,019 \\
\hline 6 & 1,867 & 294,931 & 174,710 & 108,690 & 66,021 & 46,215 \\
\hline 7 & 1,874 & 277,972 & 166,400 & 103,139 & 62,355 & 43,648 \\
\hline 8 & 1,867 & 265,062 & 160,152 & 99,956 & 60,195 & 42,137 \\
\hline 9 & 1,836 & 257,877 & 160,792 & 100,170 & 60,622 & 42,434 \\
\hline 10 & 1,856 & 239,137 & 158,033 & 98,050 & 59,983 & 41,988 \\
\hline
\end{tabular}

703

704

705

706

707

708

709

710

711

712

713

714

715

716

717

718 
719 Table 3: Proportion of area and above ground biomass in accessible, candidate and treated units to the 720 total study area.

\begin{tabular}{|c|c|c|c|c|c|}
\hline $\begin{array}{c}\text { selection } \\
\text { area }\end{array}$ & $\begin{array}{l}\text { area } \\
\text { (ha) }\end{array}$ & $\begin{array}{r}\mathrm{agb} \\
(\mathrm{t})\end{array}$ & $\begin{array}{c}\% \text { of total } \\
\text { area }\end{array}$ & $\begin{array}{c}\% \text { of total } \\
\text { agb }\end{array}$ & $\begin{array}{c}\mathrm{agb} \\
\left(\mathrm{tha^{-1 } )}\right.\end{array}$ \\
\hline landscape & 234,842 & $20,126,839$ & 100 & 100 & 86 \\
\hline accessible & 126,495 & $10,735,459$ & 54 & 53 & 85 \\
\hline candidate & 46,839 & $5,936,051$ & 20 & 30 & 128 \\
\hline treated & 18,564 & $3,048,209$ & 8 & 15 & 166 \\
\hline
\end{tabular}

721

722

723

724

725

726

727

728

729

730

731

732

733

734

735

736

737

738

739 
740 Table 4: Area treated and treatment residue at each delivered costs category.

\begin{tabular}{|c|c|c|c|}
\hline $\begin{array}{l}\text { delivered cost } \\
\qquad\left(\$ t^{-1}\right)\end{array}$ & $\begin{array}{l}\text { area } \\
\text { (ha) }\end{array}$ & $\begin{array}{l}\text { residue } \\
(\mathrm{t})\end{array}$ & $\begin{array}{l}\text { cumulative residue } \\
\text { (t) }\end{array}$ \\
\hline$<40$ & 3,153 & 56,924 & 56,924 \\
\hline $40-45$ & 25,627 & 524,154 & 581,078 \\
\hline $45-50$ & 14,915 & 321,812 & 902,890 \\
\hline$>50$ & 3,144 & 58,015 & 960,906 \\
\hline
\end{tabular}

741

742

743

744

745

746

747

748

749

750

751

752

753

754

755

756

757

758

759 


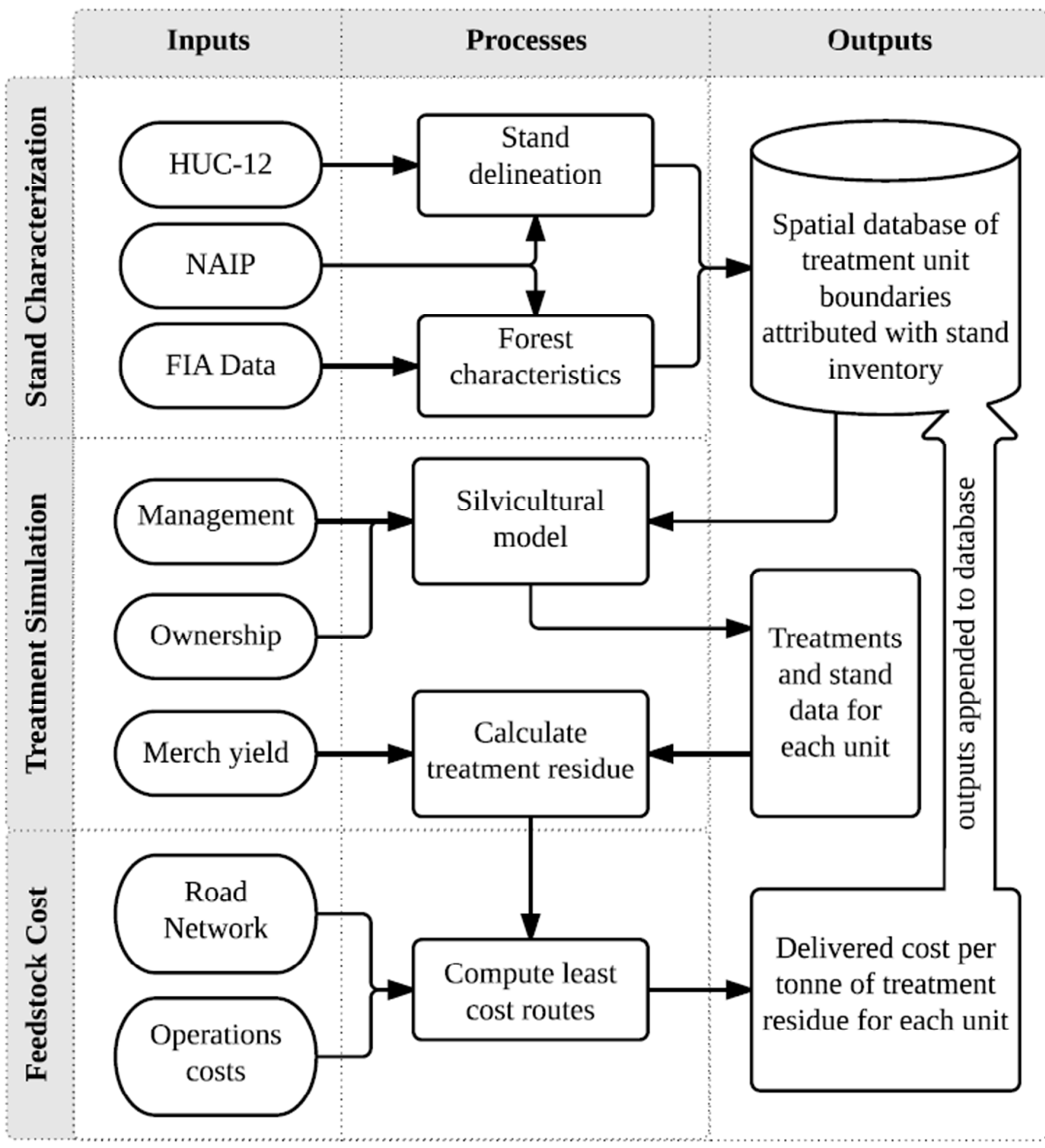

763 Figure 1: Overview of the workflow components for estimating treatment residue quantity, spatial 764 distribution and delivered costs. 


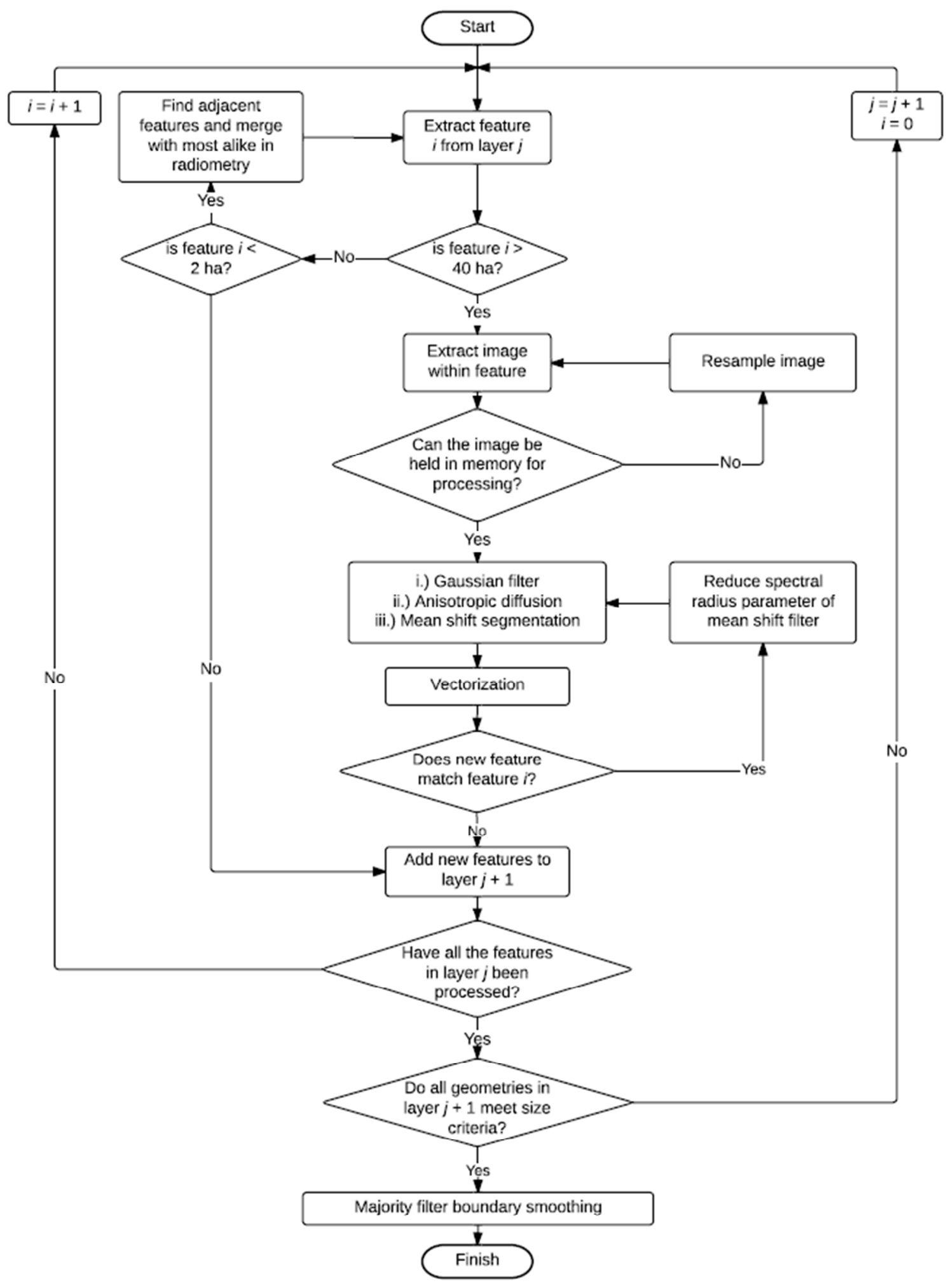

767 Figure 2: Flowchart of the stand delineation algorithm. 


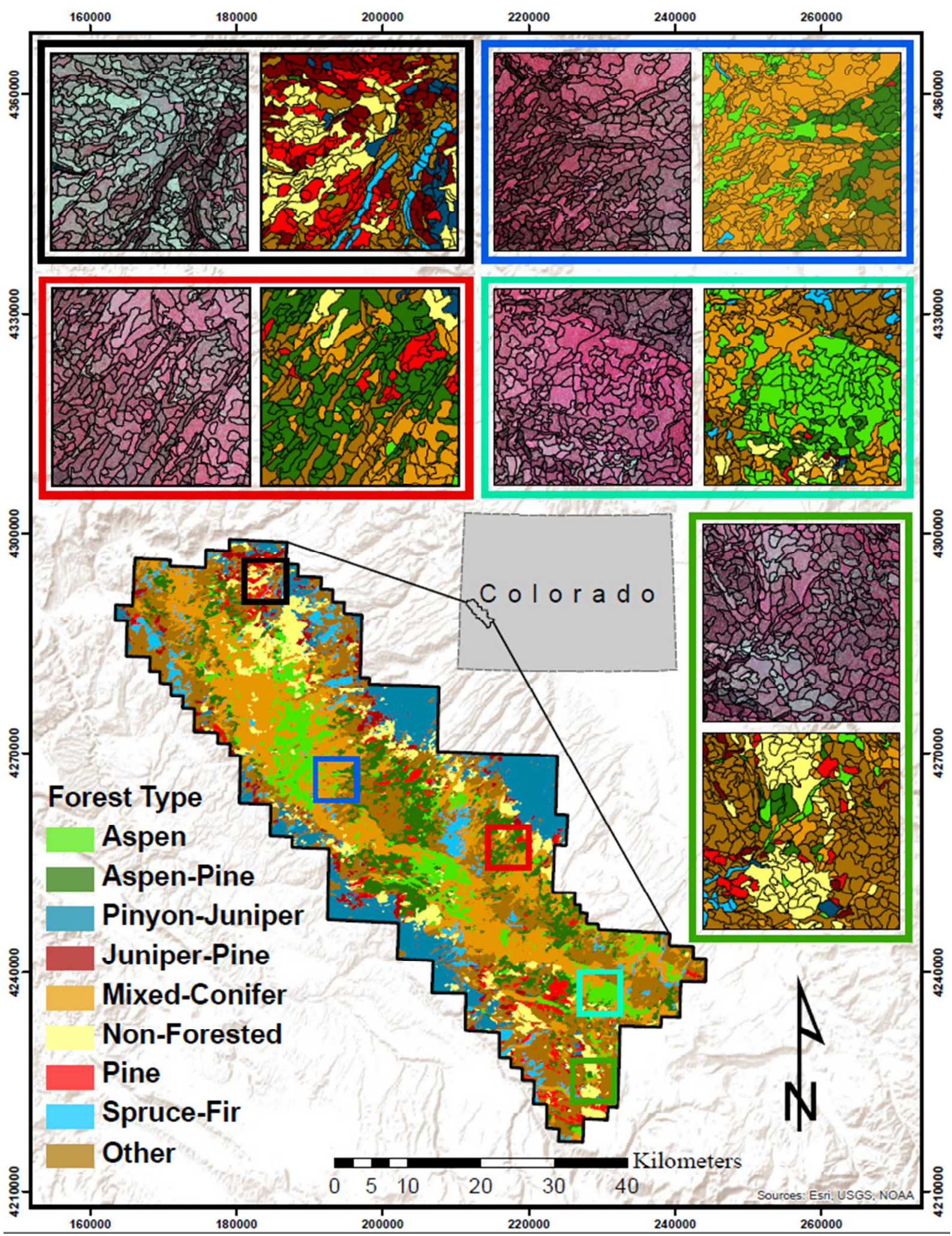

772 Figure 3: Mapped forest types across the study area. Zoomed areas show stand boundaries

773 superimposed on NAIP-CIR imagery and their respective forest type. 
(a)

(b)

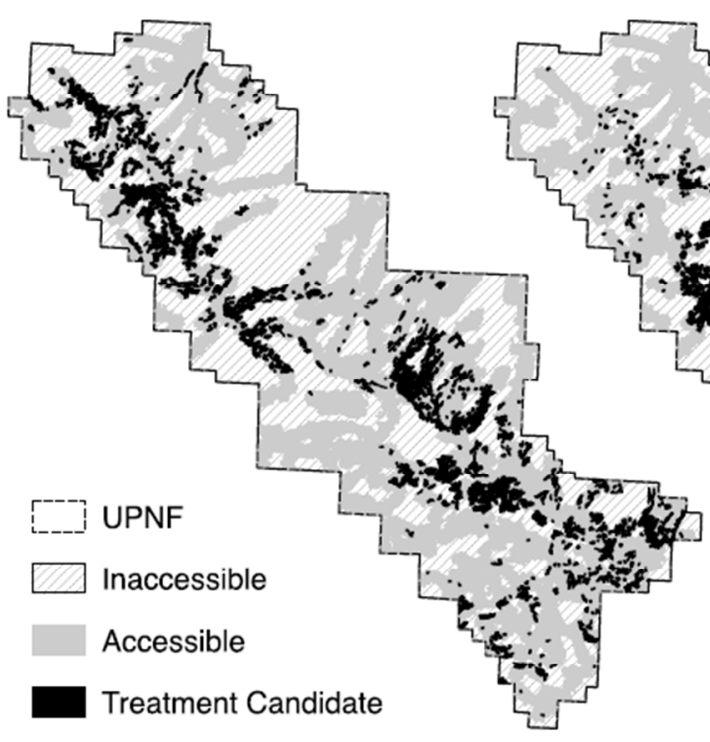

(c)

783

784

785

786

787

788

789

790

791

792

793

794

795

796

797

798

799

800

801

802

803

804
Figure 4: Candidate treatment units by silvicultural prescription. (a) Stocking-based management; $(b)$ regeneration management; $(c)$ restoration in ponderosa pine. 
805

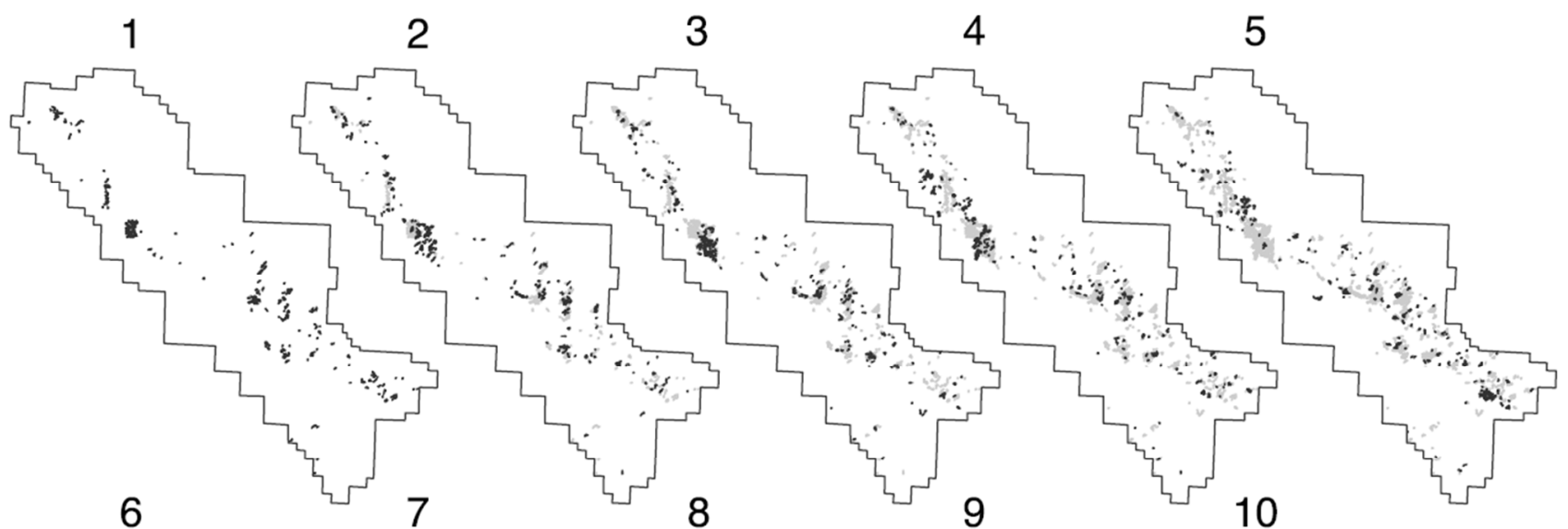

806

807

808 Figure 5: Stands selected for treatment (black) by simulation year. Grey areas show stands treated in 809 previous years.
810

811

812

813

814

815

816

817

818

819

820

821

822

823

824

825

826

827

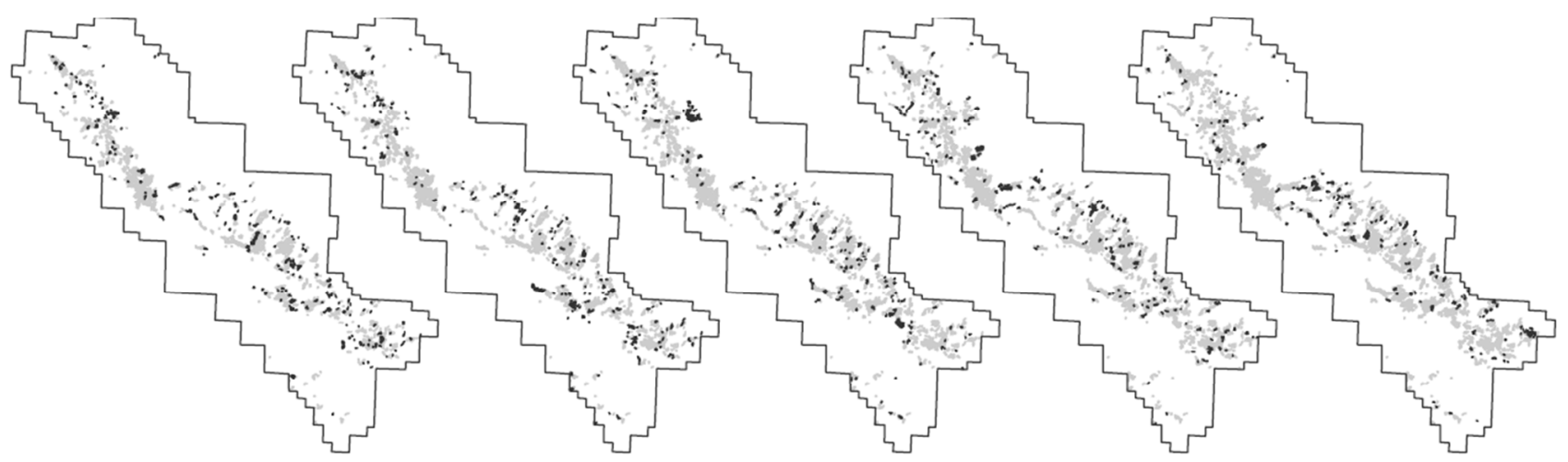

Previously treated $\quad$ Selected for treatment 


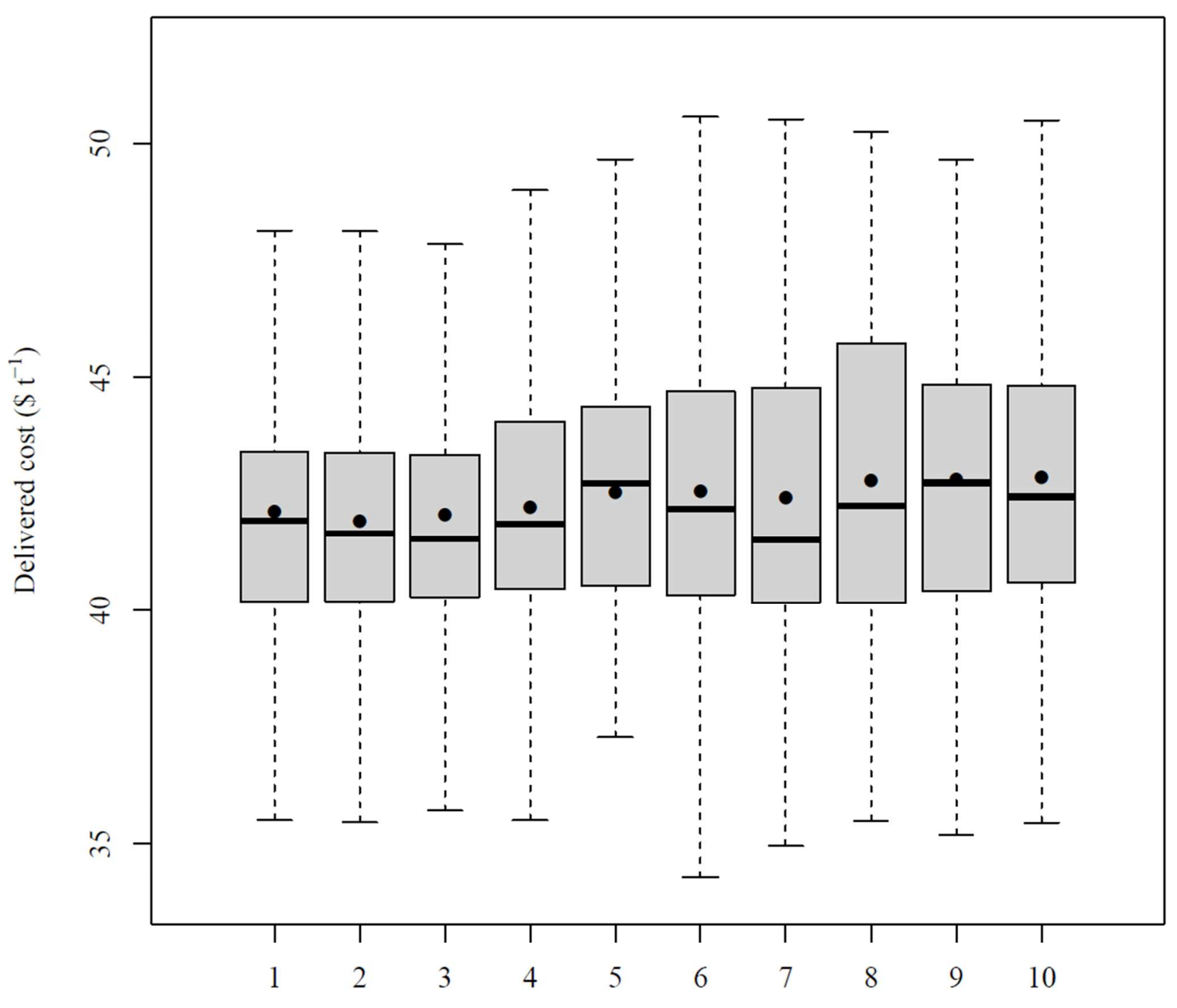

Figure 6: Distribution of operations costs per year. Black lines represent the median costs and points represent average costs. 


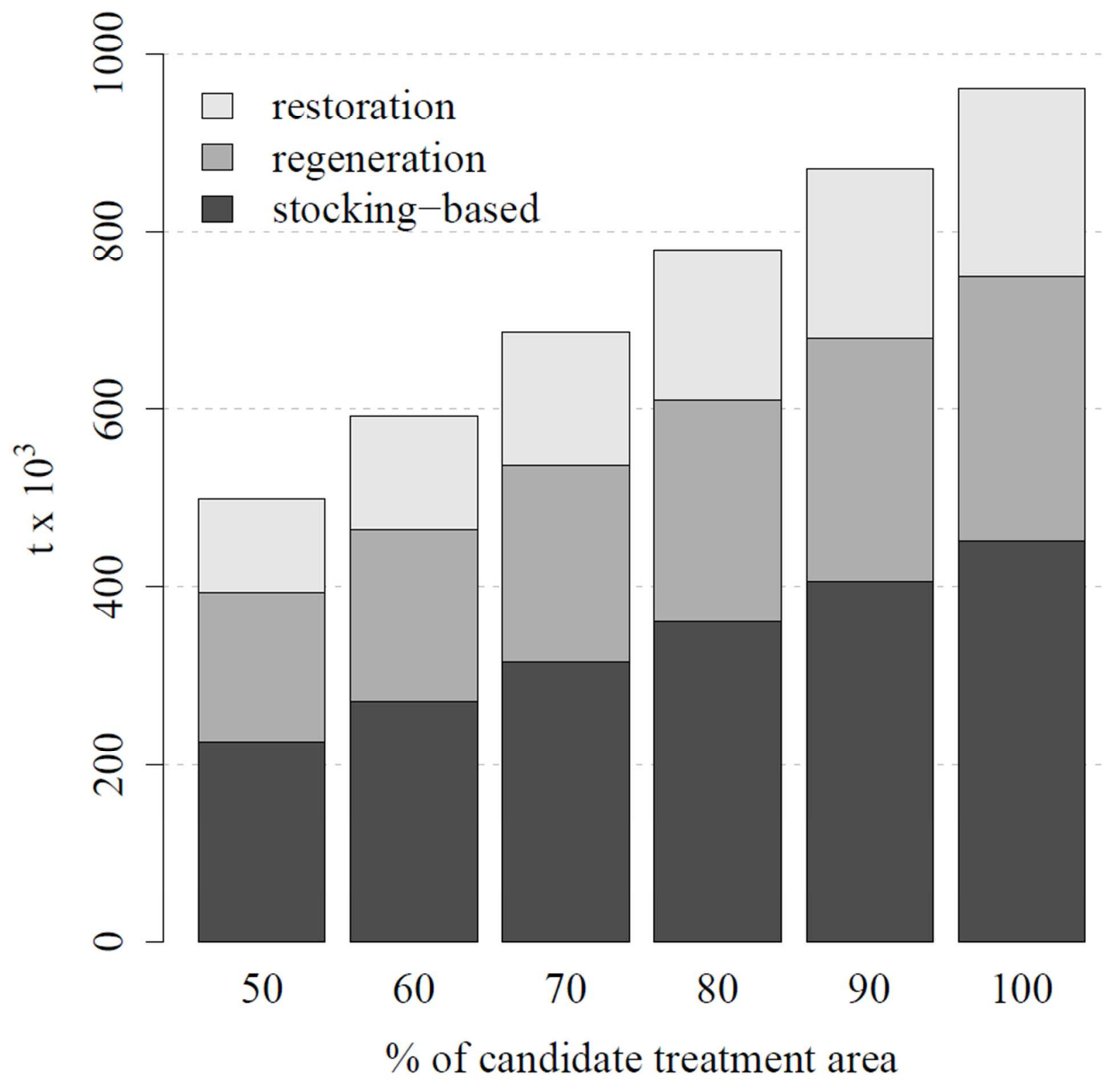

839

840

841 Figure 7: Available residue volume by silvicultural prescription at each simulated treatment level.

842

843

844

845

846

847

848

849

850 


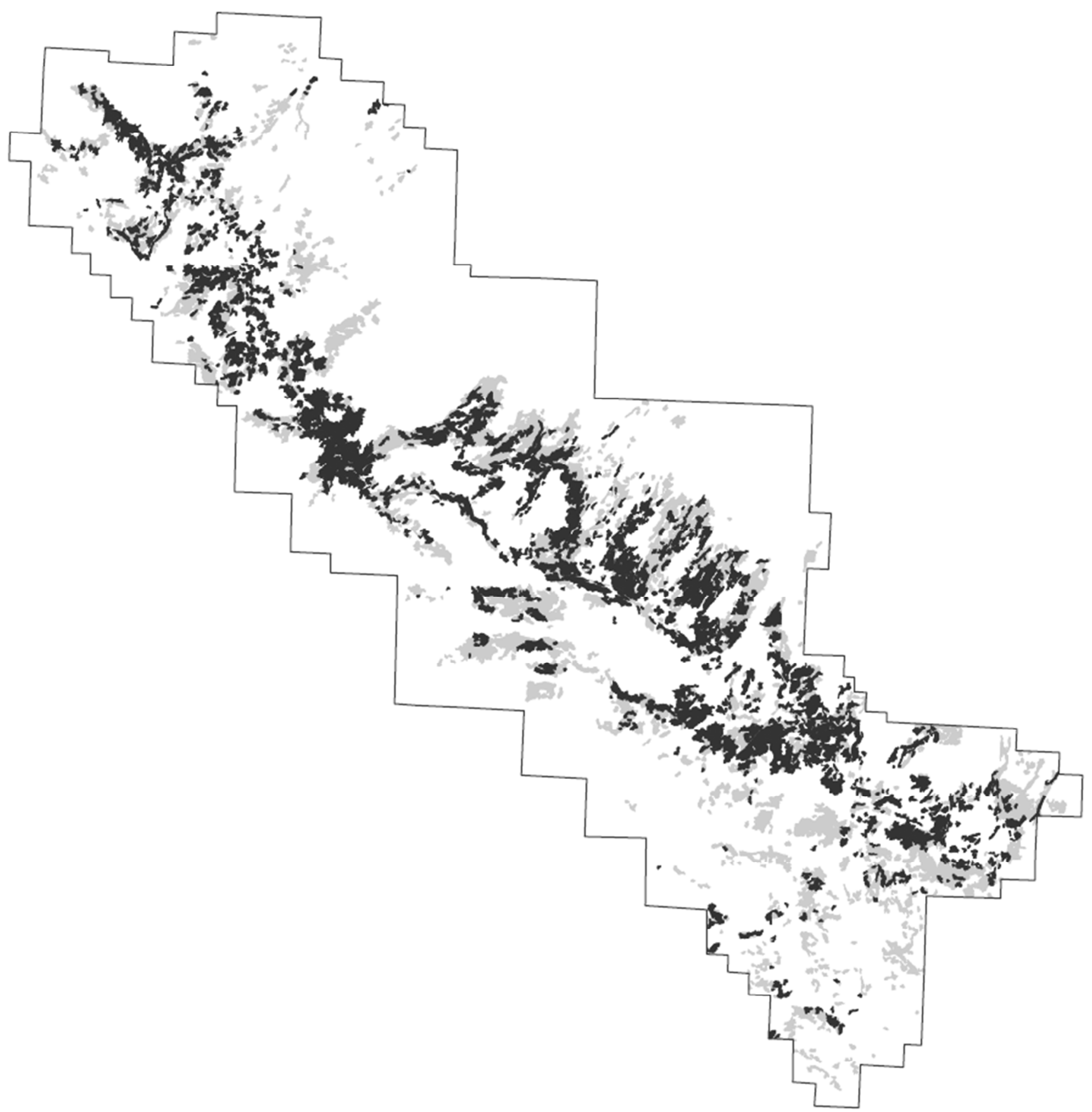

852

853

854

855

856

857

858

859

860

861
Figure 8: Change in distribution of treatments as allowable treatment area restriction increases. The black area shows stands selected at 50\% allowable treatment area and gray represents stands selected at $100 \%$ allowable treatment area. 


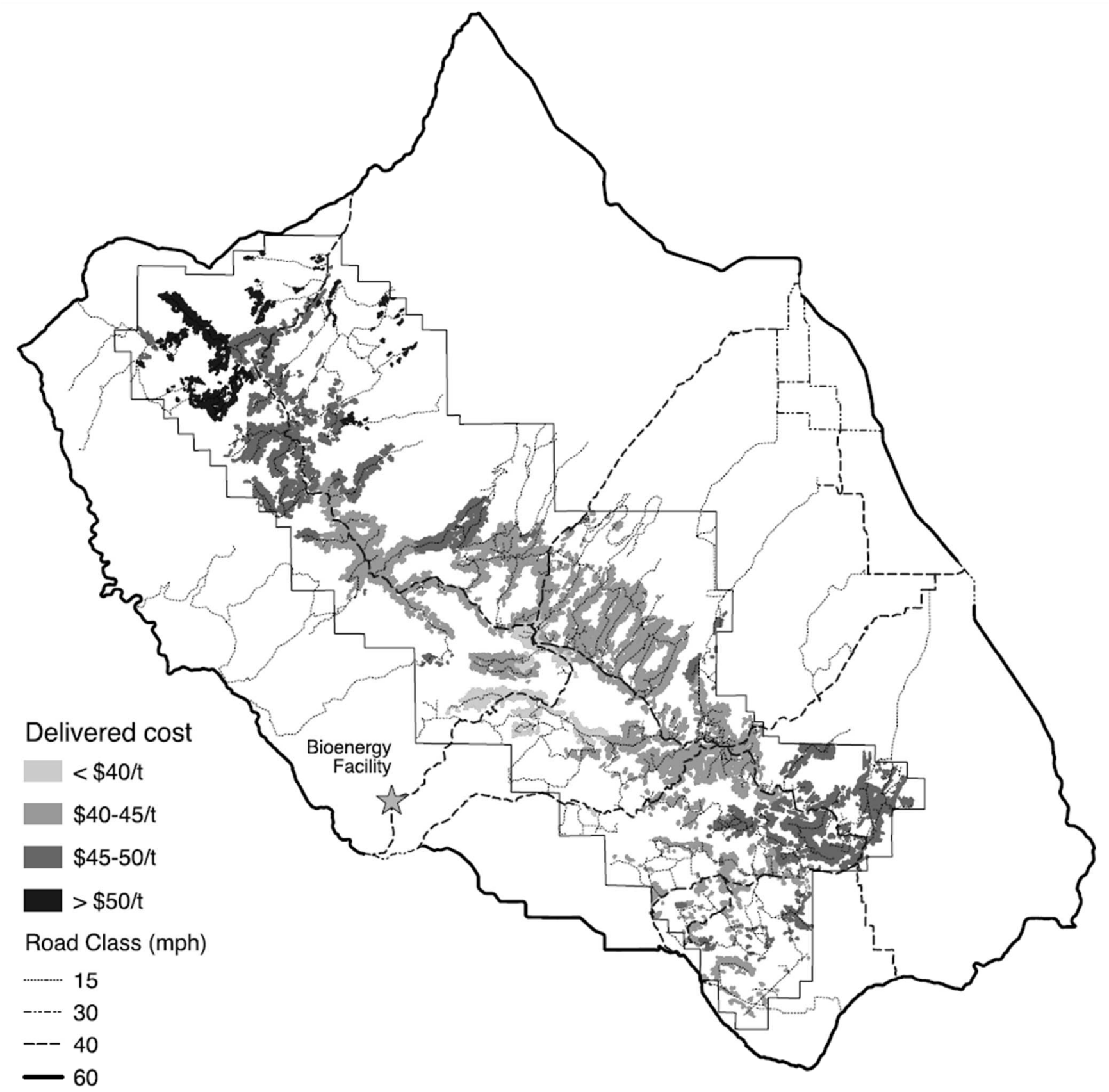

862

863

864 Figure 9: Spatial distribution of delivered costs for the candidate treatment area. Delivered costs are 865 categorized in $\$ 5$ increments.

866 